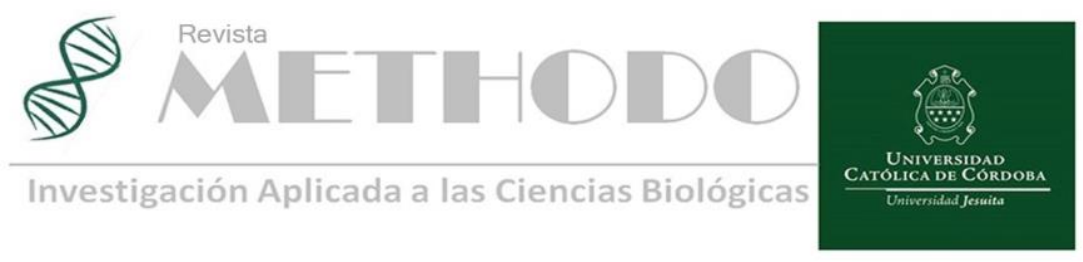

CASO CLINICO Rev. Methodo 2019;4(2):63-65 https://doi.org/10.22529/me.2019.4(2)07

Recibido 25 Sep. 2018 | Aceptado 15 Feb. 2019 | Publicado 30 Jun. 2019

\title{
Inducción de tolerancia en alergia a la proteína de leche de vaca: modelo desde un caso clínico
}

\section{Tolerance induction in cow's milk protein allergy: a clinical case model.}

\author{
Natalia Lozano ${ }^{1}$, Vanina Marini ${ }^{1}$, Alejandro Lozano, ${ }^{1}$ Ricardo Saranz, ${ }^{1}$ Graciela Alegre,${ }^{1}$ Ana Gabriela \\ Sosa Aguirre ${ }^{1}$, Eugenia Concari $^{1}$, Luciano Ianiero ${ }^{1}$.
}

1 Universidad católica de Córdoba. Facultad de Ciencias de la Salud, Clínica Universitaria Reina Fabiola Cátedra de Alergia e Inmunología. Correspondencia: Natalia Lozano Servicio de Alergia e Inmunología. Clínica Universitaria Reina Fabiola. Oncativo 1248-X5004FHP-Córdoba, Argentina; e-mail: nalozano@yahoo.com

\section{Introducción}

La prevalencia de la alergia alimentaria en pediatría presenta un incremento en los últimos años; el alimento más frecuentemente involucrado es la leche de vaca ${ }^{1}$. La alergia a proteína de leche de vaca (APLV) afecta la calidad de vida del paciente y su familia porque requiere dieta de exclusión y medicación de rescate por probables reacciones frente a ingesta accidental del alimento $^{1}$. Actualmente se está avanzando en el estudio de la inmunoterapia oral (ITO) con leche de vaca (LV) como alternativa de tratamiento ${ }^{2,3}$. Algunos estudios demuestran descenso de la $\operatorname{IgE}$ específica (IgEs) para $\mathrm{LV}^{4}$, mientras otros autores refieren que no hay cambios posteriores al tratamiento con ITO3.

\section{Desarrollo del caso}

Niño de 7 años, con diagnostico de APLV desde los 6 meses de vida basado en la presencia de urticaria, angioedema y síntomas respiratorios inmediatos posteriores a la ingesta de LV, y valores de IgEs positiva para LV (27,02KU/L), alfalactoalbumina (ALA) 32,2 KU/L, betalactoglobulina (BLG) 30,2 KU/L y caseína (CA) 39,5KU/L. Realizó dieta de exclusión de proteína de LV desde los 6 meses, con buena evolución, solo con síntomas esporádicamente por ingesta accidental. A los 5 años se realiza desafío con LV4 con resultado positivo y por lo cual se inicia tratamiento con ITO con $\mathrm{LV}^{5}$. La fase de inducción del tratamiento desensibilizante tuvo una duración de 12 meses $\mathrm{y}$, actualmente, se encuentra en fase de mantenimiento con $200 \mathrm{ml}$ de LV por día. En los estudios complementarios se ha observado disminución de IgEs para LV, ALA, BLG y CA, tanto en pruebas cutáneas por puntura de lectura inmediata (Figura 1) como en el nivel sérico de las mismas (Figura 2). Actualmente se encuentra libre de síntomas frente a la ingesta de proteínas de LV.

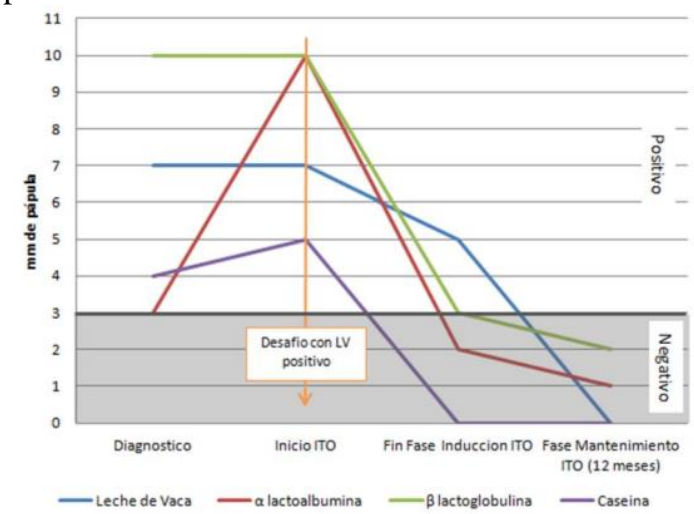

Figura 1: Resultado de prueba cutánea por puntura de lectura inmediata para leche de vaca y para cada una de sus proteínas. ITO: inmunoterapia Oral. LV: Leche de vaca.

Revista Methodo: Investigación Aplicada a las Ciencias Biológicas. Universidad Católica de Córdoba. Jacinto Ríos 571 Bo Gral. Paz. X5004FXS. Córdoba. Argentina. Tel.: (54) 3514517299 / Correo: methodo@ucc.edu.ar / Web: methodo.ucc.edu.ar | CASO CLINICO Rev. Methodo 2019;4(2):63-65 


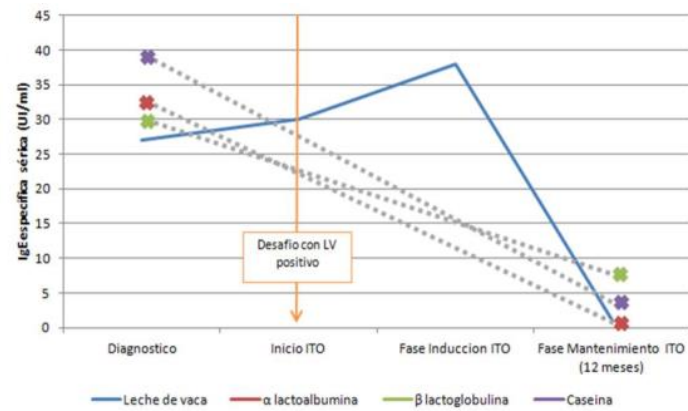

Figura 2: Valores de IgE específica sérica para leche de vaca y para cada una de sus proteínas. ITO: Inmunoterapia Oral. LV: Leche de vaca.

\section{Conclusión}

En el caso presentado, se evidencia descenso de las IgEs, en un paciente con APLV bajo tratamiento con ITO, como expresión de la inducción de tolerancia inmunológica, lo cual se correlaciona con la evolución clínica del niño.

\section{Introduction}

The prevalence of food allergy in paediatrics has increased in recent years; the most frequent food involved is cow's milk1. Allergy to cow's milk protein (CMPA) affects the quality of life of the patient and his or her family because it requires exclusion diet and rescue medication for probable reactions to accidental food intake1. There are currently advances in the study of oral

\section{Bibliografía:}

1. Wood RA. Food allergen immunotherapy: Current status and prospects for the future. J Allergy Clin Immunol. 2016;137:973-82.

2. Martorell A, Alonso E, Echeverría L, Escudero C, et al. Oral Immunotherapy for Food Allergy: A Spanish Guideline. Immunotherapy Egg and Milk Spanish Guide (ITEMS Guide). Part I: Cow Milk and Egg Oral Immunotherapy: Introduction, Methodology, Rationale, Current State, Indications, Contraindications, and Oral Immunotherapy Build-up Phase. J Investig Allergol Clin Immunol 2017; 27(4): 225-237.

3. Martorell A, Alonso E, Echeverría L, Escudero C, et al. Oral Immunotherapy for immunotherapy (OIT) with cow's milk (CM).2,3 Some studies show a decrease in specific IgE (IgEs) for CM, while other authors refer no changes after treatment with OIT3.

\section{Case development}

7-year-old boy, diagnosed with CMPA from 6 months of age based on the presence of urticaria, angioedema and immediate respiratory symptoms following intake of $\mathrm{CM}$, and positive IgEs for CM (27.02KU/L), alpha-lactoalbumin (ALA) 32.2 $\mathrm{KU} / \mathrm{L}$, beta-lactoglobulin (BLG) $30.2 \mathrm{KU} / \mathrm{L}$ and caseine (CA) $39,5 \mathrm{KU} / \mathrm{L}$. The child starts on a CMexcluding diet from 6 months of age, with good evolution and only has sporadic symptoms after accidental ingestion. At 5 years of age he has a positive $\mathrm{CM}$ challenge 4 and therefore initiates treatment with ITO. The induction phase of the desensitizing treatment lasted 12 months and is currently undergoing maintenance phase with $200 \mathrm{ml}$ of CM per day. Complementary studies have shown a decrease in IgEs for CM, ALA, BLG nd CA in both skin prick tests (Figure 1) and serum level (Figure 2). Actually, he is symptom-free against intake of $\mathrm{CM}$ proteins.

\section{Conclusion}

In the case presented, a decrease in IgEs is evidenced in a patient with CMPA under OIT treatment, as an expression of the induction of immunological tolerance, which is correlated with the clinical evolution of the child.

Food Allergy: A Spanish Guideline. Immunotherapy Egg and Milk Spanish Guide (ITEMS Guide). Part II. J Investig Allergol

Clin Immunol 2017; 27(5). Doi: 10.18176/jiaci.0178

4. Sampson HA, Gerth van Wijk R, BindslevJensen C, MD, Sicherer S, MD, et al. Standardizing double-blind, placebocontrolled oral food challenges: American Academy of Allergy, Asthma \& Immunology-European Academy of Allergy and Clinical Immunology PRACTALL consensus report. J Allergy Clin Immunol 2012; 130 (6): 1260-1274.

5. Meglio P, Bartone E, Plantamura M, Arabito $\mathrm{E}$, et al. A protocol for oral desensitization in children with IgE-mediated cow's milk allergy. Allergy 2004: 59: 980-987 
Lozano N, Marini V, Lozano A, Saranz R, Alegre G, Sosa Aguirre AG, Concari E, laniero L. Inducción de tolerancia en alergia a la proteína de leche de vaca: modelo desde un caso clínico.

\section{Palabras claves:}

INMUNOTERAPIA, DESENSIBILIZACIÓN,

IGE ESPECÍFICA, ALERGIA ALIMENTARIA

\section{Keywords:}

IMMUNOTHERAPY, DESENSITIZATION, SPECIFIC IGE, FOOD ALLERGY

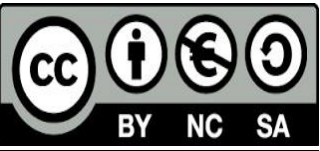

